\title{
高周波輪郭焼入れ歯車用鋼の開発
}

\author{
井上幸一郎* , 紅林 豊*
}

\section{A New Steel for Induction Contour Hardened Transmission Gears}

\author{
Koichiro Inoue, and Yutaka Kurebayashi
}

\section{Synopsis}

The induction contour hardening is an effective process to strengthen automotive transmission gears with the minimal distortion. Its heating time, however, is too short, 0.15 to $0.3 \mathrm{sec}$, to fully austenitize the ferrite-pearlite structure in normalized conventional steels, such as $545 C$, which are now quenched and tempered before the hardening. Authors extracted the effect of alloying elements on the austenitizing behavior and then designed a new steel, 0.55C-0.1Si-1.2Mn-0.1Cr$0.001 B($ in $w t \%)$. It bears almost the single phase of pearlite as normalized and is transformed into the homogeneous martensite by the contour hardening. The gears in the new steel contour hardened without the pre-heat-treatment possess the fatigue strength equivalent to the carburized ones in SCr42O and the impact strength three times as large as them, still the less distortion than them.

\section{1 . 緒言}

高周波焼入れは浸炭焼入れとともに機械部品の表面硬 化熱処理として広く用いられている．また，インライン化 が可能なことや浸炭焼入れに比べてクリーンて環境に優し いことなどの理由から弚の適用範囲を拡大しつつある ${ }^{1)}$. しかしながら自動車の変速機などに用いられる比較的モ ジュールの小さい歯車には通常の高周波焼入れでは歯全 体が焼入れされてしまうため高い圧縮残留応力を付与す ることができず十分な強度が得られないことや熱処理歪 みが大きいなどの問題があり, 高周波焼入れ処理は適用さ れてこなかった .

近年，エレクトロニクスの発達により高周波出力制御技 術が向上し， $0.15 \sim 0.3 \mathrm{~s}$ の極めて短時間の高周波加熱後， 急冷することによって部品形状に沿った硬化層を付与で きる高周波輪郭焼入れ技術 ${ }^{2)}$ が開発されている. 高周波 輪郭焼入れでは, 形状に沿った均一な硬化層が得られるた め非常に高い圧縮残留応力を部品に付与でき高強度化が 図れる.また，通常の高周波焼入れに比べて熱処理歪みが
小さいなどの特徵があり，従来高周波焼入れの適用が困難 とされてきた比較的モジュールの小さい自動車用ギアへ の適用 ${ }^{3)}$ が試みられている。

高周波焼入れでは短時間の加熱によって均一なオース テナイトを得る必要があることから, 通常兴の前熱処理と して焼入れ焼戻しが行われることが一般的である.しかし ながら通常の高周波焼入れでは省コスト化やリードタイ 么短縮の目的から焼入れ焼戻し処理を焼ならしに簡略化 したり，焼入れ焼戻し処理を省略して熱間鍛造ままで使用 されることが多い.高周波輪郭焼入れでは通常の高周波焼 入れに比べて加熱時間が非常に短いことから，前熱処理の 簡略または省略は困難で, 焼入れ焼戻しは必須であった .

しかしながら省コスト化の観点からは，通常の高周波焼 入れと同樣に前熱処理を焼ならしへ簡略化しても高周波 輪郭焼入れが可能な材料開発が求められている このよう な背景から自動車用の比較的小モジュールのギアに適用 可能で,前熱処理を焼入れ焼戻しから焼ならしに簡略化し ても超短時間の高周波焼入れで均質な硬化層を得ること ができる高周波輪郭焼入れ用鋼を開発したので光の特性 
を報告する ～

\section{2 . 合金設計の考え方}

高周波焼入れの前熱処理として焼入れ焼戻した場合と 焼ならした場合で最も異なるのは組織であり前者はソル バイト組織，後者はフェライト・パーライト組織を有して いる.ソルバイト組織はフェライトの基地組織に微細な炭 化物が均一分散したものであり，マクロ的には全体に均一 な炭素濃度分布を持つ組織であると考えることができる． 一方, フェライト・パーライト組織は炭素濃度が共析組成 のパーライト部とわずかな固溶炭素しか含まない初析 フェライト部から構成されており，マクロ的に見ても炭素 濃度分布が不均一になっている。

Fig.1 はフェライト・パーライト組織を加熱した場合の 炭素濃度変化を模式的に示したものである.鉄 - 炭素二元 系平衡状態图ではパーライト部の平均炭素濃度は 0.69mass\% (以下 \% は mass\%) で初析フェライト部には最 大で $0.02 \%$ の固溶炭素が存在し,フェライト・パーライト 組織は異なる炭素濃度の複合組織鋼であると考えること ができる このような組織をオーステナイト域に加熱する とオーステナイト化直後はもとの炭素濃度を継承してい るが ,時間の経過とともに炭素は旧パーライト部から旧初 析フェライト部へと拡散して兴の濃度はしだいに均一化 する.しかしながら高周波輪郭焼入れのように $0.15 \sim 0.3 \mathrm{~s}$ の超短時間加熱では炭素濃度の低いフェライト部への炭 素拡散が不十分で, 炭素濃度が不均一なまま焼入れられる ことがある.このような現象はマクロ的な炭素濃度の不均 一をなくすこと，すなわち前組織の初析フェライトをでき るだけ少なくし，パーライト単一組織とすることによって 防止できる .

焼ならし後に超短時間の高周波焼入れを施しても不均 質な硬化層組織が生じない高周波輪郭焼入れ用鋼の組成 をTable 1 に示す.従来からの知見より $0.55 \%$ 程度の炭素 を含有すれば高周波焼入れ後に浸炭焼入れ材と同等の転 動疲労強度を得られることが知られている.このため開発 鋼の炭素含有量も $0.55 \%$ とした .また炭素含有量が $0.55 \%$ では焼ならしままでパーライト単一組織にはならないの で,マンガン含有量により焼ならし後の組織をパーライト 単一組織になるように調整している.さらにパーライト単 一組織でもできるだけ硬さを低減することを目的として シリコン含有量を通常の炭素鋼に比べて低減した .ホウ素 は高周波焼入れ後の硬化層の勒性向上のために添加した .

Fig.2 に $0.55 \% \mathrm{C}-0.1 \% \mathrm{Si}-0.1 \% \mathrm{Cr}-0.001 \% \mathrm{~B}$ 鋼を $1123 \mathrm{~K}$ で 焼ならした後の初析フェライト面積率と硬さに及ぼすマ
ンガン含有量の影響を示す.また, 焼ならし後の光学顕微 鏡組織もあわせて示した .マンガン含有量の増加にともな い初析フェライト面積率は減少し,マンガン含有量が $1.2 \%$ で初析フェライト面積率は約 $3 \%$ 程度でほぼパーライト単 一組織になる.この結果から開発鋼のマンガン含有量を $1.2 \%$ と決定した . また , 焼ならし硬さはマンガン含有量 の増加によって増加するが，ほぼパーライト単一組織の $1.2 \% \mathrm{Mn}$ 鋼で $220 \mathrm{HV}$ 程度であり，歯車に適用する場合の 歯切り加工も可能な硬さ水準である .



Fig.1. Schematic illustration of change in carbon distribution with heating time.

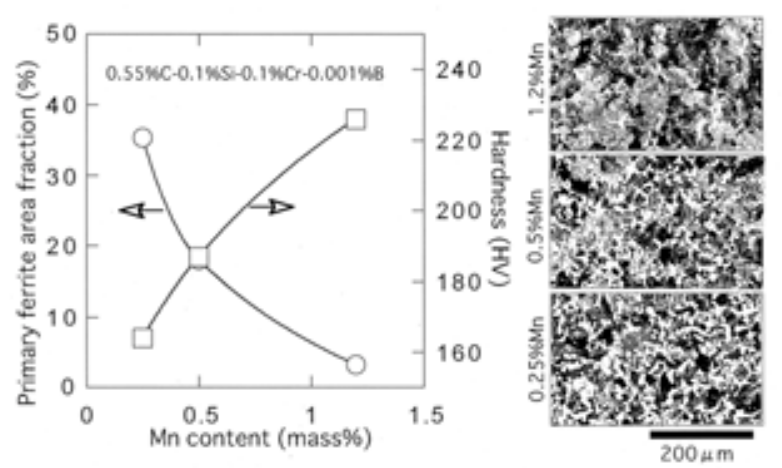

Fig.2. Influence of manganese content on primary ferrite area fraction, hardness, and microstructure after normalizing at $1123 \mathrm{~K}$.

Table 1. Chemical composition of developed steel.

\begin{tabular}{c|c|c|c|c}
\hline $\mathrm{C}$ & $\mathrm{Si}$ & $\mathrm{Mn}$ & $\mathrm{Cr}$ & $\mathrm{B}$ \\
\hline 0.55 & 0.1 & 1.2 & 0.1 & 0.001 \\
\hline
\end{tabular}




\section{3. 開発鋼の高周波焼入性}

Fig.2で示した 0.55\%C-0.1\%Si-0.1\%Cr-0.001\%B 鋼でマン ガン含有量を変化させた鋼の高周波焼入れ性を調査した 結果を以下に述べる. Fig.3 は焼ならし後の初析フェライ 卜面積率が3\%の開発鋼とマンガン含有量によって焼なら し後の初析フェライト面積率を $18 \%$ と $35 \%$ に変化させた 鋼を高周波加熱により $1173 \mathrm{~K}$ まで $0.15 \mathrm{~s}$ で加熱した後に水 冷した表層の光学顕微鏡組織である.前述したように旧初 析フェライト部への炭素の拡散が不十分であることに起 因した黑く腐食される領域を有する不均質なマルテンサ イト組織や未変態の残留フェライトなどか認められる。

$1173 \mathrm{~K}$ までの加熱時間を $0.45 \mathrm{~s}$ と $1.5 \mathrm{~s}$ として同樣に硬化 層組織を観察した結果，および有効硬化層深さの変化を Fig.4 に示す.初析フェライト面積率が 18\% と 35\% の $0.5 \% \mathrm{Mn}$ 鋼と $0.25 \% \mathrm{Mn}$ 鋼では $0.45 \mathrm{~s}$ 加熱でも未变態の残留 フェライトが観察され，加熱時間を $1.5 \mathrm{~s}$ まで延長しても 初析フェライト部への炭素の拡散が不十分なために硬化 層には不均質なマルテンサイトが観察される.一方, 初析 フェライト面積率が3\%でほぼパーライト単一組織を有す る開発鋼はいずれの加熱条件でも均質な硬化層組織が得 られる.また，開発鋼はいずれの加熱条件でも他の供試鋼 に比べて有効硬化層深さが深く,超短時間の加熱でも優れ た高周波焼入性を有していることがわかる ここには示さ ないが, 開発鋼では均質な硬化層組織が得られているた め, 硬化層部は安定した硬さが得られる。一方, 弚の他の 供試鋼では硬化層組織に起因して硬化層部の硬さが大き くばらつくことを確認している.以上のように開発鋼は超 短時間の高周波加熱後に焼入れても均質な硬化層組織と 安定した硬化層硬さが得られることがわかる.

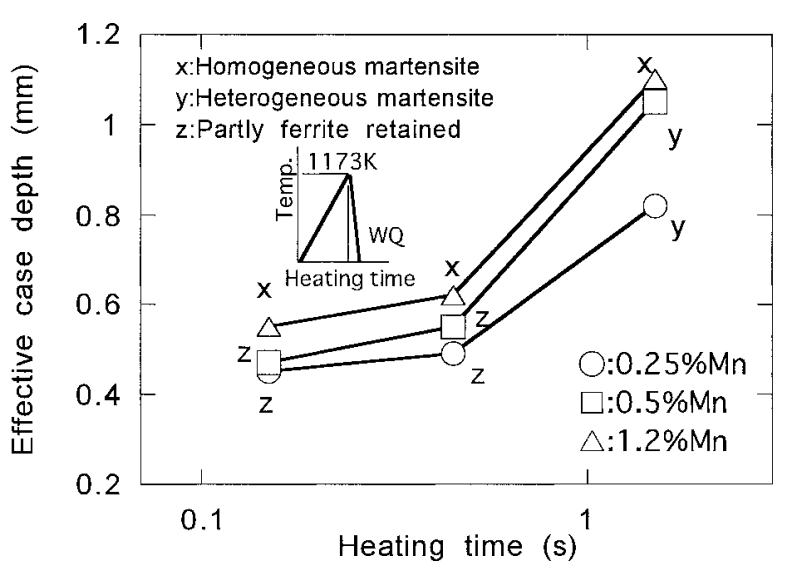

Fig.4. Influence of heating time on microstructure and effective case depth after induction heating.

\section{4 . 高周波焼入れ後の強度特性}

ここでは高周波焼入れ後の開発鋼の強度特性を歯車用 鋼として広く用いられている代表的な肌焼鋼である JISSCr420 浸炭焼入れ材と比較して示す．

Fig.5 は応力集中係数 1.8 の切欠き回転曲げ試験片での 疲労試験の結果を示したものである.この時の開発鋼の高 周波焼入れによる有効硬化層深さは 0.73 と $1.68 \mathrm{~mm}$ であ る.また, 斜線で示された範囲は同じ形状の切欠き回転曲 げ疲労試験片を用いて JIS-SCr420 浸炭焼入れ材の疲労強 度を調査したときの S-N 曲線のバンドである．

いずれの有効硬化層深さでも開発鋼に高周波輪郭焼入 れを施した試験片の疲れ限度は JIS-SCr420 浸炭材にくら べて 1.5 倍高強度である.これは高周波輪郭焼入れによっ て非常に高い压縮残留応力が付与されるためである．

切欠き回転曲げ疲労試験は歯車の歯元曲げ疲労強度を 評価する一つの指標である.開発鋼に高周波焼入れを施し た試験片の疲労強度は浸炭焼入れ材に比べて非常に高く，

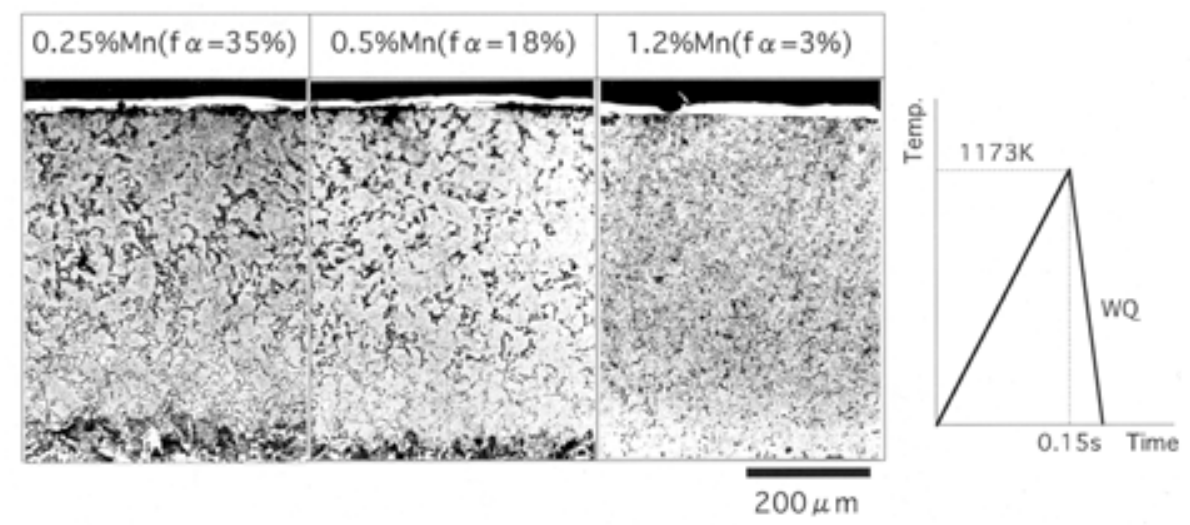

Fig.3. Influence of primary ferrite area fraction on microstructures after rapid induction heating. 


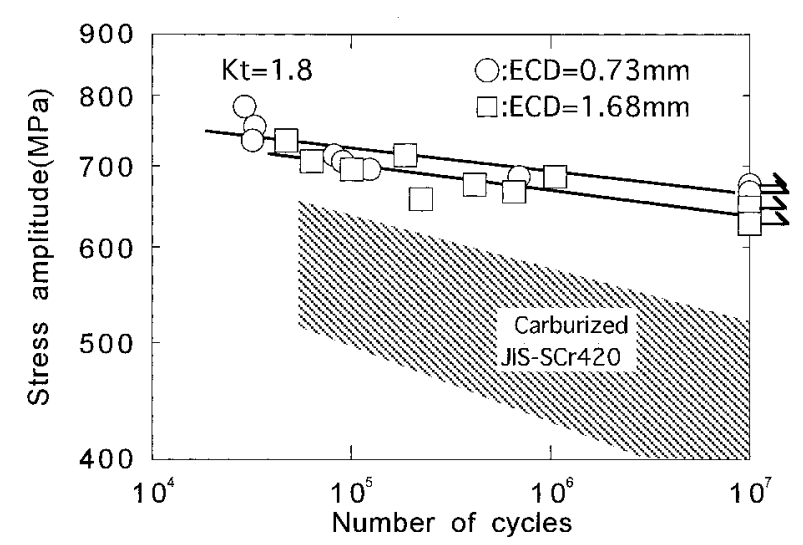

Fig.5. S-N curves of developed steel after induction hardened.

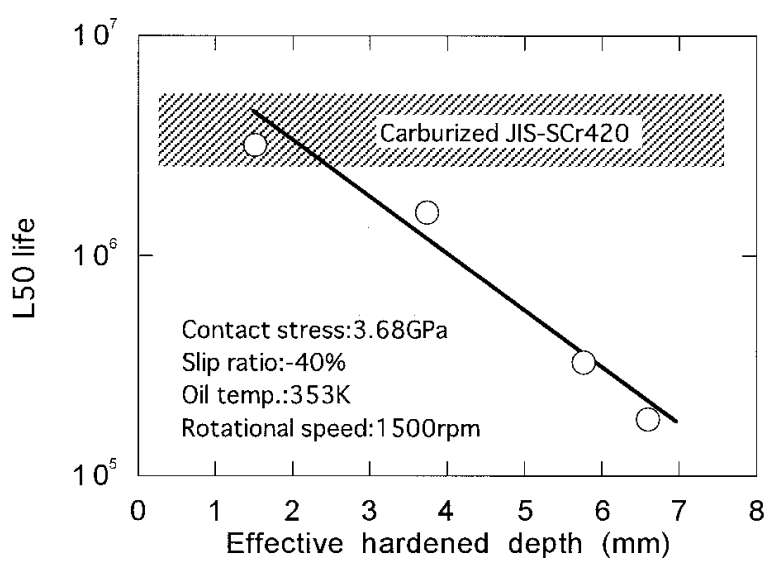

Fig.6. Relationship between effective case depth and roller pitting life of developed steel.

条件によっては高周波焼入れ歯車は圧縮残留応力の活用 により非常に高い歯元曲げ疲労強度が得られることを示 唆している.

歯車の強度は歯元曲げ疲労強度の他に歯面のピッティ ング強度が重要な特性として挙げられる.弚こで開発鋼の
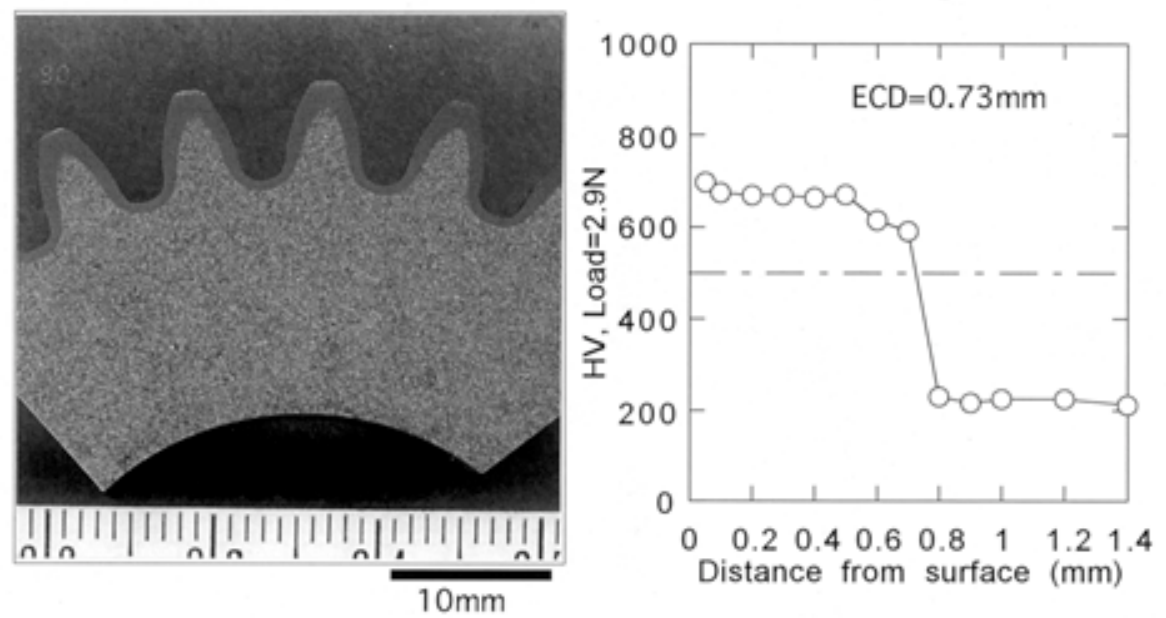

Fig.7. Case pattern and hardness distribution at tooth root of test gear.

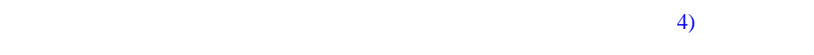
て評価した結果を Fig.6 に示す. 図中の斜線で示された領 域は JIS-SCr420 浸炭焼入れ材で同樣の試験を実施した場 合の寿命を示したものである.高周波焼入れ材では浸炭焼 入れ材に比べて比較的容易に有効硬化層深さを大きく変 化させることができるため ここでは有効硬化層深さを大 きく変化させて試験を実施した .

開発鋼のピッティング寿命は有効硬化層深さの減少と ともに向上し，本実験条件では約 $1.5 \mathrm{~mm}$ で JIS-SCr420 浸 炭焼入れ材と同等の寿命が得られる.これは有効硬化層深 さの減少にともない表面の圧縮残留応力の絶対値か増加 するため 5) であり，高周波輪郭焼入れのように歯車形状 に沿った比較的浅い硬化層を付与することがピッティン グ強度向上に有効であることを示唆している．また, 表面 炭素濃度が浸炭焼入れ材に比へてて低い開発鋼でも適切な 条件の高周波輪郭焼入れにより浸炭焼入れ材と同等程度 のピッティンク強度が得られることを示している。

開発鋼に高周波輪郭焼入れを施した歯車実体での特性 を以下に紹介する.試験に用いた歯車の諸元をTable 2 に 示す.ここでは動力循環式の歯車疲労試験機 6)を用いた 歯車実体に疲労強度評価および 2 枚の歯車をかみ合わせ 計装化されたハンマーで衝撃的に歯を破壊させる歯車衝 撃試験7)により歯車強度を評価した。

Fig.7 は開発鋼に高周波輪郭焼入れを施した歯車の断面 組織と歯元の硬さ分布である.歯車の形状に沿って硬化層 が付与されており，歯元の圧縮残留応力の絶対值は $770 \mathrm{MPa}$ であった . また，表面硬さは約 $700 \mathrm{HV}$ ，心部硬さ は約 $210 \mathrm{HV}$ で有効硬化層深さは $0.73 \mathrm{~mm}$ であり，硬化層 は均質なマルテンサイト組織であった 。

開発鋼で作製した高周波輪郭焼入れ歯車と JIS-SCr420 
で作製した浸炭焼入れ歯車の歯車疲労強度試験の S-N 曲 線をFig.8 に示す.回転曲げ疲労では浸炭焼入れ材対比 1.5 倍程度の疲れ限度が得られていたが, 高周波輪郭焼入れ歯 車の疲れ限度は浸炭焼入れ歯車とほぼ同じで640MPaであ る.また，いずれの試験荷重でも歯車の歯面にピッティン グの発生は認められなかった .

開発鋼で作製した高周波輪郭焼入れ歯車の疲れ限度は 浸炭焼入れ歯車と同程度の強度が得られるが, $10^{4} \sim 10^{5}$ 回時間強度は浸炭焼入れ歯車に比べてわずかに低くなる 傾向にある .これは浸炭焼入れ歯車では焼入れ後に心部硬 さ300〜 400HV が得られるのに対して開発鋼では歯切り 被削性を確保するため心部の硬さを 200 ～230HV に抑え ているためである . $10^{4} \sim 10^{5}$ 回時間強度が要求される場 合には開発鋼にシリコン,バナジウムを添加して心部強度 を約 $300 \mathrm{HV}$ まで高め，JIS-SCr420 浸炭焼入れ材以上の低 サイクル疲労強度が得られる鋼種も開発済みである ${ }^{8)}$. ま た，心部強度を高めた鋼種はシリコン含有量増加により JIS-SCr420 以上のピッティング強度を得ることも確認し ている5). しかしながらこれらの鋼種は心部強度が高く歯 切り被削性に問題があるため, 歯出し鍛造などの新しい歯 車の加工技術と組み合わせて使用することが望ましいと 考えられる.

Fig.9に歯車衝撃試験の結果を示す，開発鋼はJIS-SCr420 浸炭焼入れ材に比べて約 3 倍の破壊荷重が必要で, 非常に 高い靭性を有していることがわかる .これは開発鋼に添加 させているホウ素が硬化層の靫性を向上させている ${ }^{9)} こ$ と，浸炭焼入れのように粒界酸化層が存在しないこと，さ らに超短時間の加熱による高周波焼入れのため硬化層組 織が極めて微細であるためと考えられる .

開発鋼に高周波輪郭焼入れを施した歯車と JIS-SCr420 浸炭焼入れ歯車の熱処理歪みを比較したものを Fig.10に 示す.浸炭焼入れでは歯車全体をオーステナイト域から焼 入れるために大きな熱処理歪みが生じることを避けるこ とができない.一方, 高周波輪郭焼入れは必要最小限の領 域をオーステナイト域に加熱した後に急冷して硬化させ るため, 変態による歪みの発生は浸炭焼入れにくらべて小 さく，最小限に抑制することが可能である．Fig.10からも 明らかなように開発鋼に高周波輪郭焼入れを施した歯車 は JIS-SCr420 浸炭焼入れ歯車に比べて熱処理歪は小さく 抑えられている.
Table 2. Dimensions of test gear.

\begin{tabular}{l|c}
\hline \multicolumn{1}{c|}{ Module } & 2.5 \\
\hline Pressure angle & $20 \mathrm{deg}$. \\
\hline Number of teeth & 28 \\
\hline Pitch circle diameter & $70 \mathrm{~mm}$ \\
\hline Hexlix angle & 0 deg.(Spur) \\
\hline
\end{tabular}

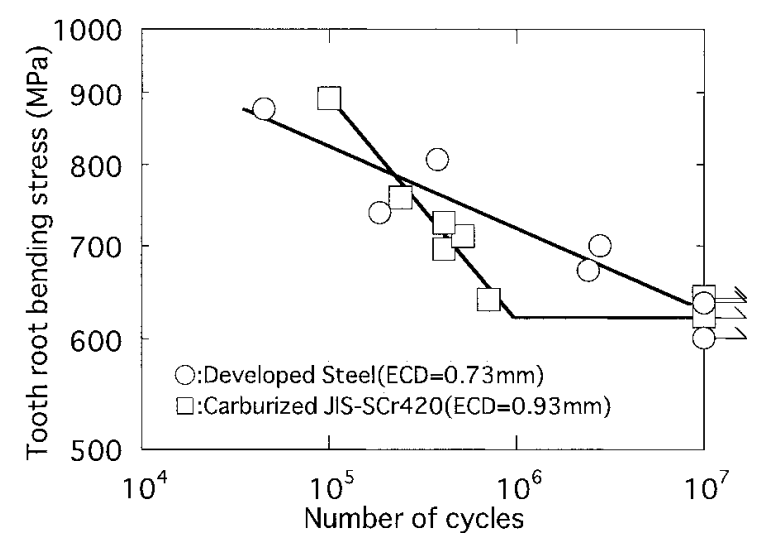

Fig.8. Comparison of S-N curves with contour hardened developed steel and carburized JIS-SCr420.

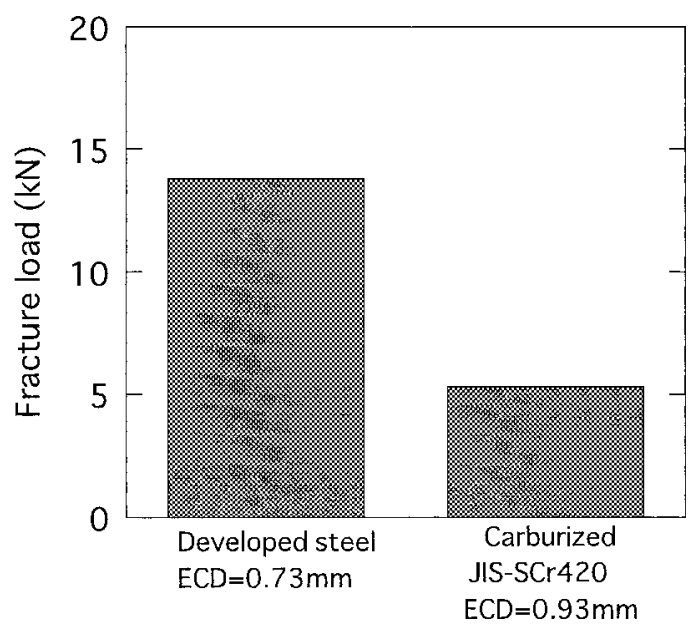

Fig.9. Fracture load of contour hardened developed steel and carburized JIS-SCr420.
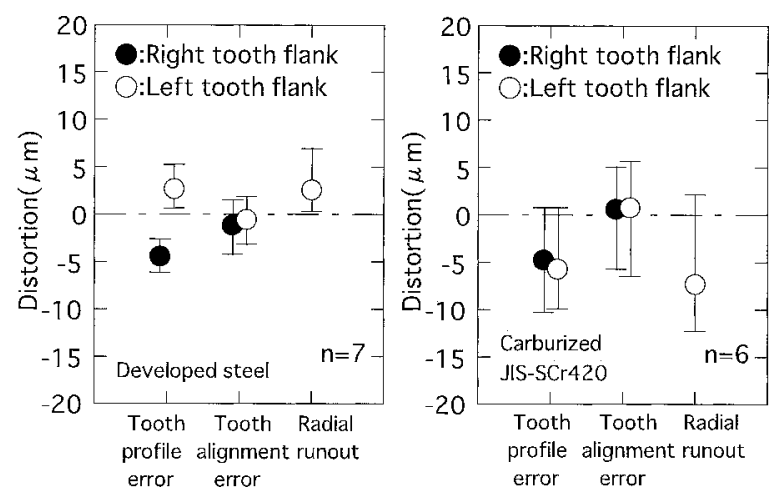

Fig.10. Comparison of gear distortion with contour hardened developed steel and carburized JIS-SCr420. 


\section{5 . 開発鋼の被削性}

本開発鋼は歯車への適用を前提に開発したためホブに よる歯切り被削性が重要な特性の一つになる.1123K て焼 ならした開発鋼のホブによる歯切り被削性を他の鋼と比 較して Fig.11 に示した . 開発鋼焼ならし材は JIS-SCr420 焼ならし材に比べて硬さが高いため歯切り被削性は低下 し, 加工能率すなわち同じ工具寿命を得るための加工速度 の比率で比較すると JIS-SCr420 焼ならし材対比 $1 / 2$ 程度で ある.これは, 超短時間加熱でも均一な硬化層組織を得る ために焼ならしままでパーライト単一組織を得なければ ならないこと, 前述した樣にある程度の $10^{4} \sim 10^{5}$ 回時間 強度を確保する目的から心部硬さをあまり大きく低下さ せることができないためである .

一方 従来高周波輪郭焼入れに用いられてきた JIS-S45C の焼入れ焼戻し材と比較すると開発鋼焼ならし材の方が 軟らかく，開発鋼の加工能率は JIS-S45C 焼入れ焼戻し材 よりは優れている .

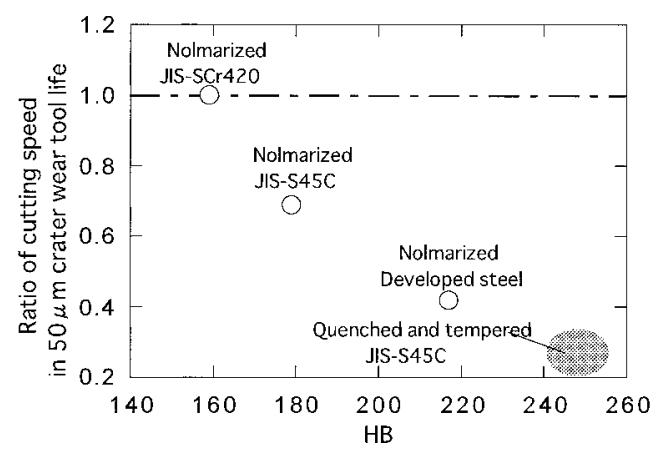

Fig.11. Relationship between hardness and machinability of developed steel and various steels.

\section{6 .まとめ}

焼ならしままで $0.15 \sim 0.3 \mathrm{~s}$ の超短時間加熱後焼入れる 高周波輪郭焼入れを施しても均質な硬化層組織が得られ る鋼を開発し光の特性を調査した。

$0.55 \% \mathrm{C}-0.1 \% \mathrm{Si}-1.2 \% \mathrm{Mn}-0.1 \% \mathrm{Cr}-0.001 \% \mathrm{~B}$ 鋼は $1123 \mathrm{~K}$ の焼 ならし後空冷することによりパーライト単層組織が得ら れ，硬さは $220 〜 230 \mathrm{HV}$ である . 焼ならし後に超短時間 加熱の高周波輪郭焼入れを施しても均質な硬化層が得ら れる．また開発鋼を用いて製造した歯車は JIS-SCr420 浸 炭焼入れ材と比較して疲労強度はほぼ同等, 衝撃強度は 3 倍であり，熱処理歪みは小さい，一方，歯切り加工能率は JIS-SCr420 焼ならし材の約 1/2 であるが，従来高周波輪郭 焼入れに用いられてきた JIS-S45C 焼入れ焼戻し材と比較 すると開発鋼の歯切り加工能率は優れている .

\section{(文 献)}

1)川㟢一博: 電気製鋼, 67(1996),44.

2)例えば Yoshitaka Misaka, Yutaka Kiyosawa, Kazuhiro Kawasaki, Takao Yamazaki, and Wilson O. Silverthorne •: SAE technical paper series No.970971,"Gear Contour Hardening by Micropulse Induction Heating System".

3)松井勝幸, 秦 博之，門川秀之:いす 技報,(1996),53.

4)木村篤良,高田勝典:電気製鋼,59(1988),27.

5)井上幸一郎，中村貞行: 電気製鋼,71(200),19.

$6)$ 並木邦夫: 博士論文” 歯車用浸炭鋼の組織制御と高強度 化に関する研究”,(1991),80.

7)並木邦夫 ,飯久保知人:電気製鋼,59(1988),5.

8)井上幸一郎, 中村貞行，三阪佳孝，川嵩一博:第46回日本 熱処理技術協会講演大会講演概要集(1998),61.

9)紅林 豊 松村康志, 中村貞行:日本鉄鋼協会生産技術部 門実用構造用鋼の材質作り込み技術検討部会編 , 実用 構造用鋼の材質作り込み技術検討部会報告書”,(200) ,19. 